\title{
INVENTIONS AND SCIENTIFIC DISCOVERIES: IMPACT OF DESIGNERS' COLLABORATIONS ON CREATIVITY. AN ANALYSIS TOWARDS FIXATION EFFECTS
}

\author{
Plantec, Quentin (1,2); Le Masson, Pascal (1); Weil, Benoit (1) \\ 1: MINES ParisTech; 2: Institut National de la Propriété Industrielle (INPI)
}

\begin{abstract}
Scientific discoveries and inventions have long been established as two distinct and sequential activities. It has nonetheless been showed that projects aiming at producing both scientific discoveries and inventions could record impressive results. Our investigations are focusing on the creativity of collaborations outputs: a first agent is entailed to design a scientific discovery and another one invention. We use fixation effects as a performance measurement indicator for creativity based on Design Theory. We propose a first set of elements that can be suffering from fixation effects in both invention and scientific models designers reasoning. We propose a series of defixed inputs that could be shared between both designers to overcome their fixation effects. We highlight that if partners are engaged in one-way knowledge transfer it can conduct to "fixation traps". We define a set of restrictive conditions that could conduct to a "cross-defixation process": both actors would be able to create conjoint new inventions and scientific models in the non-fixed design path. In particular this process does not required designers to be defixed before starting the collaboration.
\end{abstract}

Keywords: Innovation, Creativity, Human behaviour in design, Science, C-K design theory

\section{Contact:}

Plantec, Quentin

MINES ParisTech - PSL Université, Institut National de la Propriété Industrielle

Centre de Gestion Scientifique, i3 UMR CNRS 9217

France

quentin.plantec@mines-paristech.fr

Cite this article: Plantec, Q., Le Masson, P., Weil, B. (2019) 'Inventions and Scientific Discoveries: Impact of Designers' Collaborations on Creativity. An Analysis Towards Fixation Effects', in Proceedings of the 22nd International Conference on Engineering Design (ICED19), Delft, The Netherlands, 5-8 August 2019. DOI:10.1017/dsi.2019.19 


\section{INTRODUCTION}

Scientific discoveries and inventions have long been established as two distinct and sequential activities. As Vannevar Bush wrote in its report on science organisation in the United States Science the Endless Frontiere in 1945: "The simplest and most effective way in which the Government can strengthen industrial research is to support basic research and to develop scientific talent" (Bush, 1945). Science has to do with discoveries, and industry - with the help of engineering design - has to use science to create inventions. Nevertheless, the so-called "linear model" was challenged by many scholar's contributions (for example see Balconi et al. (2010) for a comprehensive literature review). In particular, Stroke's seminal contribution regarding the "Pasteur Quadrant" (Stokes, 1997) claimed that most of the famous scientists of all time have been motivated by both practical contributions (ie. inventions) and theoretical understanding (ie. discoveries) simultaneously. He found historical examples such as Pasteur, Keynes or the Manhattan project's research team. In a very recent study, Goldstein and Narayanamurti (2018) gave very clear insights regarding invention and discovery coupled dynamic. They studied the Department of Energy (DoE) in the United States between 2010 and 2015 which was organised around a sharp dividing line between a basic research department (ie. that has to do the scientific discoveries) and an applied research department (ie. that has to do the inventions). But in 2007 the DoE launched a new department called Advanced Research Projects Agency - Energy (ARPA-E) to finance projects that are at the interface between both departments: "the aim of ARPA-E appears to be funding projects that are too technology-focused to be funded as basic research but are too novel to be funded as applied research" (Goldstein and Narayanamurti, 2018, p. 1507). Authors showed that projects conducted through ARPA-E get impressive results: 57\% of ARPA-E projects get either one patent (ie. invention) or one significant scientific publication (ie. discovery) while the average for other projects is only $27 \%$. But then why not always conducting projects encompassing both fundamental research and inventions? As shown by Calvert (2006) in an international qualitative study, many scholars and policy makers consider that basic research is characterised by serendipity: unpredictability and generality of findings would be a driver for radical innovations. But in order to achieve those results, it has to be performed following a curiosity driven manner: "Basic science produced plenty only so long as university researchers were left alone, unhampered by demand for short-term results or particular products" (Slaughter, 1993, pp. 284-285). And organisation that clearly separate those activities can record high performances in terms of science and inventions. For example the largest Public Research Organisation (PRO) in France, the Commissariat à l'Energie Atomique et aux Energies Alternatives (CEA), is still organised with two distinct department regarding fundamental research ("CEA Science" and inventions ("CEA Tech"). In 2017, first, CEA Sciences recorded similar scientific publication performances than the MIT or Max Planck organisations. Second, CEA Tech, with six time less employees than Fraunhofer Geselshaft, filled 608 patents which is almost the same number of patents than the German PRO (Comptes, 2018).

In this apparently inconclusive debate we focused our investigations on a particular aspect of scientific and invention collaboration performances: the capacity to provide new scientific models and inventions that are "creative" or "original". This is an important stake as we can assume that it could be a starting point for radical innovations, even if it has to be coupled with additional factors such as business model, consumers' attempts, marketing, etc. There are many contributions in engineering design regarding creativity and originality when designing a particular artefact. Literature is nevertheless scare from our understanding regarding science. As performance indicator, we use the concept of fixation effects. It illustrates a situation in which a designer is locked-in in a specific design path and is not able to propose other significantly different solutions. Those not reached solutions are then call "creative" or "original". The research questions are then the following: in science - industry collaboration, how could the scientific partner help the industrial one to overcome its fixations effects regarding the design of an invention? Reciprocally, how could the industrial partner help the scientific one to overcome its fixations effects regarding the design of a scientific discovery?

To reach this goal it is necessary to draw on a unified model of invention and scientific discoveries that helps to highlight those fixation effects. Design Theories have been helpful to model inventions which is a core historical objective in Design Theories. It has also been showed recently that Design Theories are a powerful resource to model scientific discoveries. In particular C-K theory is a unified model of Design Theories that (1) allows us to model both invention and scientific discoveries, (2) has been previously 
showed as a key resource to model fixation effects (Agogué and Le Masson, 2014), and (3) has been previously showed as a useful theoretical framework to model partnership effects (Gillier, Kazakçı and Piat, 2012), in particular regarding science - industry partnership (Klasing Chen et al., 2017). We then first briefly recall to reader $\mathrm{C}-\mathrm{K}$ theory basic reasoning and we propose a model of invention and scientific discoveries according to this framework. Second, we draw on those models to show what fixation effects designers of inventions and scientific models can suffer from and what resources available help them to overcome those fixations. Third, we present a dynamic model of interactions between both designers to highlight conditions under which actors are able to overcome their fixations.

\section{A MODEL OF SCIENCE AND INVENTION REASONNING THROUGH DESIGN THEORIES: HIGHLIGHTS OF FIXATION EFFECTS}

\subsection{C-K Design Theory and fixations effects}

$\mathrm{C}-\mathrm{K}$ Design Theory aims at providing a unified and rigorous framework for design and has been initially developed by Hatchuel and Weil $(2003,2009)$. In particular, its ability to describe the generation of new objects and new knowledge has been highlighted both in academic literature and following industrial use. The theory is based on the interplay between two distinct but interdependent spaces. First, the knowledge space $(\mathrm{K})$ contains all propositions with a logical status (ie. true or false) regarding available knowledge that a designer is able to draw on to perform its design activity. Second, the concept space (C) contains all propositions regarding outputs or objects set up by the designer but neither true nor false according to the state of the designer's knowledge. Indeed, when designers are faced with concepts, they cannot affirm whether such a thing may be possible or not. Those concepts are the partially unknown outputs or objects. Those propositions are qualified as "undecidable" relative to the content of the knowledge space $(\mathrm{K})$ if it is not possible to prove that these are true of false. The $\mathrm{C}$-space has a tree structure and each node represents a partition in sub-concepts. Furthermore, during the design process, both concept and knowledge spaces are expandable following four possible transformations: $\mathrm{C} \rightarrow \mathrm{K}$ (ie. conjunction); $\mathrm{K} \rightarrow \mathrm{C}$ (ie. disjunction); $\mathrm{C} \rightarrow \mathrm{C}$ (ie. partitions) and $\mathrm{K} \rightarrow \mathrm{K}$. In particular, the design process attempts to define a conjunction: to transform an "undecidable" proposition in the concept space into a logical proposition in the knowledge space.

$\mathrm{C}-\mathrm{K}$ theory has allowed further theoretical development regarding fixation effects. Indeed, as the theory helps to represent different design path, it has been used to show how a designer could be locked-in in a specific design path and then not able to explore more innovative path without being "defixed" (Agogué, 2012; Agogué et al., 2014). In particular, the literature in management identified some innovations pathways do not seem achievable for a specific firm due to lack of knowledge, lack of absorptive capacity or its own historical pathway depending on its starting point and hazardous events (Sydow, Schreyögg and Koch, 2009). Kaplan and Tripsas (2008) introduced the notion of "cognitive path dependence" by showing how actors select ideas within a collective cognitive framework around a dominant technological trajectory. Thrane et al. (2010) then highlighted how collective cognitive framework can lead to constrain the exploration of alternatives. In particular, some fixation effects occur at a cognitive level due to the fact that people tend to generate ideas the most accessible in memory which might le ad to fixation effects (Hatchuel, Le Masson and Weil, 2011). Agogué and Le Masson (2014) distinguish two forms of ideation reasoning. The first is a fixated reasoning based on the use of cognitive routines calling for existing solutions with stable paradigms. It tends to maintain already existing solutions and favour incremental innovation. If a whole innovation team involved in an ideation process adopted those reasoning - which is likely to be the case in a same organisation due to common constraints - incremental outcomes will not be challenged. The second is a more explorative reasoning that lead to propose more creative and disruptive ideas through a controlled exploration of alternatives. In particular it has been shown with simple tasks how fixation effects constrain creativity and how examples outside the fixed design-path help actors to stimulate their creativity through expansive concepts (Agogué, 2012; Camarda et al., 2017).

\subsection{Modelling invention through Design Theory}

Invention is the "accumulation and creation of knowledge that results in a new tool, device, or process that accomplishes a specific purpose" (Narayanamurti, Odumosu and Vinsel, 2017, pp. 31-32). 
To simplify our model we consider inventions only as patentable ones. This help us to draw on the literature in engineering design regarding what are the core criteria associated with invention. We acknowledge that there is a debate regarding originality of patent inventions and that it might exist high or law quality patents (cf. patent rating issues). Nevertheless, as we are focusing on creativity and originality of inventions the $\mathrm{C}-\mathrm{K}$ theory will help us to classify inventions regarding design paths.

Drawing on C-K formalism, Sincholle (2009) and Le Masson et al. (2014) defined patents in an "Action - Effect - Knowledge" model in order to avoid an approach only based on legal and intellectual property. They proposed a patent content taxonomy comprising of three elements. Action is defined as the solution brought by the invention (ie. intervention made on objects). Effects comprise of the action's effects on specific objects (ie. consequences brought by the action). Knowledge comprise of initial state of the art $\left(K_{0}\right)$ and the results of the new action or effect. This model highlights a first patentability criteria: novelty. It is described by the following elements : "(1) An invention shall be considered to be new if it does not form part of the state of the art. (2) The state of the art shall be held to comprise everything made available to the public by means of a written or oral description, by use, or in any other way, before the date of filing of the European patent application" (art. 54 of the European Patent Convention). According to the model, it verifies the following formalism: $\left(A_{1}, \ldots, A_{n} \rightarrow E_{1}, \ldots, E_{n}\right) \not \subset K_{0}$. This model help us to define another key patentability criteria: the inventive step. "An invention shall be considered as involving an inventive step if, having regard to the state of the art, it is not obvious to a person skilled in the art" (art. 56 of the European Patent Convention). For example, if the person skilled in the art is capable to pose a similar problem than the one in the patent application, to solve it similarly to the proposed invention and to predict the results: the inventive step is not valid. It means that inventions cannot be the result of a new combination of already existing knowledge that the person skilled in the art (PSA) could have done (Le Masson, Weil and Hatchuel, 2014), then formally: $(\mathrm{A} \rightarrow \mathrm{E}) \not \subset P S A\left(K_{0}\right)$. In particular, the "C-K invent" method (Felk et al., 2011; Kokshagina et al., 2014) highlights that the inventive step can be modelled through an expansive partition, not related to $P S A\left(K_{0}\right)$, that expands the concept space. This expansive partition: "significantly modify or propose new actions and effects to generate new sentences - new ideas for patent proposals" (Kokshagina et al., 2014, p. 405).

Based on this brief literature review, we can formulate the following assumptions regarding the design of an invention, understood as a patentable one:

- Assumption 1.1 - state of the art knowledge acquisition: a designer has to acquire a significant knowledge base relevant to its invention field (including a comprehensive state of the art comprising all available public data) in order to both design its invention and guarantee its novelty.

- Assumption 1.2 - expansive partition: a designer has to create a concept that is a new expansive partition not related to $P S A\left(K_{0}\right)$. The invention will be the result of a conjunction (ie. the new concept become true according to the designer's knowledge base).

\subsection{Modelling science through Design Theory}

Discoveries are "creation of new knowledge and facts about the world" (Narayanamurti, Odumosu and Vinsel, 2017, p. 32). Hatchuel et al. (2013) proposed a formalism of scientific discoveries through Design theories. According to the authors, discoveries are based on a scientific method which requires a logic of modelling and the core of the scientific conversation is then to focus on the consistency, validity, testability of models and to make advancement regarding how models are fitting with existing or experimentally provoked observations. They established the following assumptions:

- Observability: the object of scientific modelling $X_{i}$ is observable through observations $x_{i}$ and it is assumed that observing those $x_{i}$ do not provoke the existence of $X_{i}$;

- Consistency \& completeness: scientific models can be express through a consistency function (ie. defining the quality of the scientific reasoning such as no contradiction, no redundancy, etc.) and a completeness function (ie. quality of the relationship between the model's predictions and observations $x_{i}$ ).

- Anomaly existence: the model aims to reduce two types of knowledge anomalies: (1) a lack in the consistency function or (2) an apparition of new observations $Y$ (directly observable or provoked) that are not predicted by the model.

- Not yet observable unknown object existence: facing anomalies, scientist make the hypothesis that there may be an unknown object $X^{\prime}$ observable but not yet observed. The aim of the scientific 
process is either to elaborate $K\left(X^{\prime}\right)$ that would provide a definition of $X^{\prime}$ and validate its expected properties or to get more observations $x^{\prime}$ to confirm the existence of $X^{\prime}$.

By drawing on this model, we can formulate the following assumptions regarding the design of a scientific discovery:

- Assumption 2.1 - knowledge acquisition: a designer has to acquire a significant knowledge base regarding existing scientific models relevant in its discovery field. Indeed, the designer has to be capable of (1) identifying an anomaly regarding previous scientific models and (2) elaborating new models or improving consistency and completeness functions of previous models.

- Assumption 2.2 - expansive partition: a designer has to provoke an expansive partition regarding its $\mathrm{C}$-space according to two strategies to make a discovery:

- Assumption 2.2.a: a designer could improve consistency and completeness functions of previous scientific models and provoke new expansive partitions regarding those models;

- Assumption 2.2.b: a designer could propose new scientific models which would be expressed through new expansive partitions.

\section{SCIENCE \& INDUSTRY FIXATIONS: DEFINITION, ORIGINS AND MITIGATION STRATEGIES}

\subsection{Objects of science and industry fixations and main influential factors}

Scientific discoveries and inventions designers are suffering from a couple of fixations effects. We first define what elements of the design process are suffering from those effects. Second we define what would be the main factors that sustain those fixations. By drawing on the definition of scientific modelling and invention below, the object of fixations are the following:

Table 1. Science \& invention elements of reasoning that could be the object for fixations

\begin{tabular}{|c|c|}
\hline Science & Invention \\
\hline $\begin{array}{l}\text { Object of scientific modelling (ie. } \\
\text { studied dimension of an object); } \\
\text { Scientific hypotheses (ie. consistency } \\
\text { and completeness functions); } \\
\text { Methodologies and scientific equipment } \\
\text { \& tools (ie. observations methods); } \\
\text { Anomaly detection and interpretation } \\
\text { (ie. observations and comparison with } \\
\text { previous scientific models); } \\
\text { Results and findings (ie. designed } \\
\text { concepts). }\end{array}$ & $\begin{array}{l}\text { - Technological paradigm (mastered } \\
\text { technologies and technology combinations) } \\
\text { to produce action and effects); } \\
\text { Relevant scientific models of those } \\
\text { technological paradigm (associated } \\
\text { knowledge); } \\
\text { - Artefact type that is produced by the } \\
\text { industry and its competitors (and associated } \\
\text { production process). }\end{array}$ \\
\hline
\end{tabular}

We then propose a taxonomy of factors that increase fixation effects through the adoption of fixed reasoning. Those factors can conduct scientific model and invention designers to stay in less creative design paths. Organisations can try to work on those factors to favour defixation processes.

Table 2. Factors that strengthen designers' fixation effects

\begin{tabular}{|c|c|c|}
\hline & Science & Industry \\
\hline Economic factors & $\begin{array}{l}\text { Economic incentives that researchers } \\
\text { received to stay in non-creative } \\
\text { design path to maximise their } \\
\text { probability to publish high-ranked } \\
\text { scientific journal articles (eg. rewards } \\
\text { based on scientific journal ranking). }\end{array}$ & $\begin{array}{l}\text { Economic incentives that inventors } \\
\text { received regarding working on } \\
\text { artefacts in core technological } \\
\text { paradigm of the company (eg. reward } \\
\text { based on the acceptance of the } \\
\text { company to finance a patent filling } \\
\text { procedure - which is not likely to be } \\
\text { the case if the invention is not part of } \\
\text { the strategic plan of the company). }\end{array}$ \\
\hline Social factors & $\begin{array}{l}\text { Social incentives to stay in fixed } \\
\text { design path regarding peer }\end{array}$ & $\begin{array}{l}\text { Social incentives to stay in fixed } \\
\text { design path regarding peer }\end{array}$ \\
\hline
\end{tabular}




\begin{tabular}{|c|l|l|}
\hline & $\begin{array}{l}\text { recognition and acceptance in } \\
\text { laboratories, particular scientific } \\
\text { discipline or groups. }\end{array}$ & $\begin{array}{l}\text { recognition and acceptance in other } \\
\text { invention designer social groups in } \\
\text { the industry or in the organisation. }\end{array}$ \\
\hline $\begin{array}{c}\text { Organisational } \\
\text { factors }\end{array}$ & $\begin{array}{l}\text { Orientation given by science } \\
\text { programmes, funding, grants and } \\
\text { strategic priorities regarding fixed } \\
\text { design paths. }\end{array}$ & $\begin{array}{l}\text { Orientation and funding given by } \\
\text { R\&D department or strategic } \\
\text { priorities given by management } \\
\text { (following for example previous } \\
\text { company investments) }\end{array}$ \\
\hline Individual & $\begin{array}{l}\text { Use of cognitive routines calling for existing solution with stable paradigms } \\
\text { in designer process. }\end{array}$ \\
\hline
\end{tabular}

\subsection{Mitigation of fixation effects through science-industry interactions}

As shown in Agogué and Le Masson (2014) works, examples outside the fixed design path help designers to propose more creative solutions. In science-industry partnerships, invention and scientific model designers would be able to exchange defixated inputs. Following the linear model logic, it is well documented how a scientist could bring defixated inputs to invention designer through new fundamental discoveries that lead new inventions (eg. the Manhattan project has been extensively used as a core example $\left.{ }^{1}\right)$. As a more recent case, graphene synthetisation discovery in 2004 by A. Greim is illustrative (Nobel Prize 2010). Indeed, following his fundamental discovery of new carbon forms as a new material, a couple of industries are reviewing potential applications such as new transistor generation. Nevertheless, the phenomenon is less documented regarding what defixed examples industrial can bring to scientific model designer. We propose the following list of inputs and associated probabilities ("prob.") regarding historical examples.

Table 3. Defixating inputs of invention's designer to scientific discovery's designer

\begin{tabular}{|c|c|c|c|}
\hline Fixation issue & Prob. & Details & Example \\
\hline $\begin{array}{l}\text { Object of } \\
\text { scientific } \\
\text { modelling }\end{array}$ & Medium & $\begin{array}{l}\text { New industrial stakes for } \\
\text { companies that lead to study } \\
\text { other dimensions of an existing } \\
\text { object; } \\
\text { New object created by industry. }\end{array}$ & $\begin{array}{l}\text { Bipolar-contact transistor invented } \\
\text { in Bell labs by Shockley, Bardeen } \\
\text { and Brattain that conduct to new } \\
\text { scientific discoveries regarding its } \\
\text { effects. }\end{array}$ \\
\hline $\begin{array}{l}\text { Methodologies } \\
\text { and scientific } \\
\text { equipment \& } \\
\text { tools }\end{array}$ & Medium & $\begin{array}{l}\text { - New scientific tools created by } \\
\text { the industry to detect new } \\
\text { observations. }\end{array}$ & $\begin{array}{l}\text { The quantum computing developed } \\
\text { by major IT companies and its } \\
\text { effects on calculation possibilities } \\
\text { for physics analyses. }\end{array}$ \\
\hline $\begin{array}{l}\text { Anomaly } \\
\text { detection and } \\
\text { interpretation }\end{array}$ & High & $\begin{array}{l}\text { Industrial issues that require } \\
\text { scientific advances to be solved. }\end{array}$ & $\begin{array}{l}\text { Pasteur and the invention of the } \\
\text { microbiology following its } \\
\text { intervention with North of France } \\
\text { brewers (cf. also case study on } \\
\text { CRISPR in section } 4.3 \text { ) }\end{array}$ \\
\hline $\begin{array}{l}\text { Results and } \\
\text { findings }\end{array}$ & Low & $\begin{array}{l}\text { New results due to large scale } \\
\text { testing centres of the industry or } \\
\text { real condition testing. }\end{array}$ & $\begin{array}{l}\text { Higgs' Boson and new scientific } \\
\text { knowledge due to the testing of its } \\
\text { theory in LHC. }\end{array}$ \\
\hline
\end{tabular}

\section{DYNAMIC ANALYSIS OF SCIENCE-INDUSTRY INTERACTIONS: FIXATIONS TRAPS \& CROSS-DEFIXATION PROCESSES}

In order to define science-industry implications on the exploration of more creative design paths we are drawing on the "matching-building" model developed by Gillier et al. (2012). The latter is useful to demonstrate effects of partnerships on knowledge and concept bases of each actor. We then call "Agent A" the designer of the new invention and "Agent B" the designer of the new scientific model. We assume that at the beginning of the partnership, both actors are fixed in their own specific design path.

${ }^{1}$ On this topic, see Lenfle (2011) for further discussions 


\subsection{Matching phase}

In the matching phase, actors involved in the partnership investigate together their own C-K frame to identify intersections. If actors are sharing similar concepts or knowledge need, they can engage common exploration or knowledge transfer in order to provoke partitions and new conjunctions.

Regarding new inventions and scientific models designers, if there is a match between their concepts or knowledge need (1) at least one expansive partition has already been carried out by agent A and/or agent B and (2) those expansive partitions occurred in the fixed path. Two particular cases can be highlighted. The first is referring to the "Mode 2 knowledge production" (Gibbons et al., 1994): agent B is able to provide to agent A the required knowledge to help the latter to provoke a conjunction in its $\mathrm{C}-\mathrm{K}$ frame which constitute a new invention. It is describing the classical model of research commercialisation. For example an industrial asks a research team to solve a particular problem taking in account all its industrial constraints such as past investments, consumer needs, etc. The second is referring to "reverse mode 2": agent A is able to provide to agent B the required knowledge to help the latter to provoke a conjunction in its $\mathrm{C}-\mathrm{K}$ frame. It is referring to a situation in which for example the industrial partner is able to bring an invention to help to scientific model validation (Narayanamurti, Odumosu and Vinsel, 2017). It has to be noted that the actor that is transferring knowledge also learns from the process and then can be able to provoke new partitions in its C-space: new inventions and scientific models then appear in a sequential model.

Regarding fixation effects in those cases, it has to be noted that the initial partition is associated to the fixed design path, as well as the conjunction following the partnership. Nevertheless the party that provide the knowledge and learn from the exchange process could be able to access to defixating inputs from the other partner (see section 3.2). The probability remains low because those cases mainly describe one-way transfer. Indeed, the partner that initially ask for knowledge transfer does not need to extensively share its own knowledge except for very detailed specifications limited to the adaptation of what is being transferred. Worse, it can give fixed examples that will strengthen fixation effects. If new inventions and new scientific models occurs, (1) it is highly probable that both outputs are linked to fixed design path and (2) occur in a sequential modes. We then call those situations "fixation traps".

\subsection{Building phase}

The building phase occurs when actors do not find relevant intersection between their different $\mathrm{C}-\mathrm{K}$ frames. It means that (1) they do not have many interaction between their knowledge base and (2) they are committed to define both new inventions and new scientific models: actors need to "build" a shared and relevant concept between them. In that phase, partners are collecting in a first time information about each other which is "an opportunity for partners not only to expand their concept and knowledge spaces but, more interestingly, to revisit them" (Gillier, Kazakç1 and Piat, 2012, p. 386). In a second time, interactions between both actors will conduct them to "imagine a more abstract concept that could interest all of them" (Gillier, Kazakç1 and Piat, 2012, p. 386) that can lead to highly expansive partitions. For agent A and B we interpret this bi-directional exchange of knowledge as a factor that increase the probability of sharing a defixated input such as new dimensions of an object for scientific modelling. The engagement of agent B to favour agent A's new inventions also helps to recognize anomalies regarding previous scientific model following phenomenon reported by agent A. Second, the fact that both actors have to imagine a more abstract concept in particular help agent A to being defixed regarding traditional industry constraints and be more open to more creative design path.

We have to notice that under a set of conditions that drive this building phase, agents A \& B are able to engage in what we call a "cross-defixation process": both partners are able to share an abstract concept and to then acquire and exchange new knowledge to favour conjunctions in non-fixed design path. The particularity of this cross-defixation process is that it conducts both actors to generate creative output but in a conjoint mode. We propose a synthesis vision of the required conditions:

- Condition 1: Agents A \& B do not share pre-existing concepts (or at least are not entailed to work on them) - this condition is referring to the building stage;

- Condition 2: Agents A \& B have a significant knowledge base relevant to their field of activities that support their capacity to provoke partitions - this condition is referring to the capacity to bring novelty and new scientific models; 
- Condition 3: There is limited intersection between agents A \& B knowledge base - this is a condition referring to building stage (if not we assume that they would be able to match some concepts);

- Condition 4: Agents A \& B are ready to both (1) reassess their own knowledge bases and (2) favour bi-direction knowledge exchange in order to find a shared area of interest - this condition is referring to the capacity of both actors to overcome fixation effects.

- Condition 5: Agents A \& B are highly committed to both obtain a very practical answer to the invention designer and a model with high consistency and completeness standard for the scientific discovery designer - this condition is referring to overcome anomaly detection and interpretation fixation effects.

\subsection{Case study: CRISPR \& Danisco company - a case of cross-defixation}

In this section we illustrated our results through a brief recent case study on CRISPR-Cas9, a fundamental discovery in genome editing ${ }^{2}$. Based on cross-checked sources regarding CRISPR ${ }^{3}$, we are focusing here on the contribution of an agri-food industrial company called Danisco.

In its business unit of Dangé-Saint-Romain (France), Danisco was producing bacterial starter cultures for cheeses and yogurts production. In 2004-2005, the company launched an R\&D project focusing on a particular lactic-acid bacteria (Streptococcus thermophilus). The latter was intensively used in the production process but were sometime attacked by viruses (ie. bacterial phage) with high financial implications for the company. More surprising, when attacked by phage, Danisco showed that some bacteria were able to protect themselves against the viruses while some other died. The $R \& D$ project's goals were then (1) to better understand this phenomena and (2) to propose new industrial processes to favour bacteria survival. To perform this project, the company appointed P. Horvath as team leader, an experienced scientist specialized in microbiology and acid lactic DNA.

We reinterpreted this case by using the framework described in the upper section. Agent A is represented by Danisco who aim to design a new industrial process to favour bacteria preservation. Agent $B$ is represented by the research team who aim to design a new scientific discovery regarding this phenomena. Both designers have acquired a significant knowledge base in their respective domains. Indeed, for Agent A, bacterial starter culture is the core industrial process (the company at Dangé-Saint-Romain was established in 1964 already on this market). For Agent B, P. Horvath got his $\mathrm{Ph} . \mathrm{D}$. from Strasbourg University where he was focusing on genetics of lactic-acid bacteria for food production (Condition 2). Nevertheless, their knowledge base remain distinct for the project as $\mathrm{P}$. Horvath was appointed for its expertise on acid lactic DNA following the acquisition by Danisco of a DNA sequencer (Condition 3).

Regarding the matching - building model, agent A and B do not share pre-existing concepts regarding this topic as they were not able to transfer available piece of knowledge to directly solve the issue (Condition 1). P. Horvath's team was able to reinterpret the industrial issue as a scientific anomaly: how some micro-organisms, such as a bacteria, could be able to protect themselves from virus phage while their pairs do not? Indeed, according to available scientific models at that time, bacteria strains cannot protect themselves without having similar responses to phage. Due to this anomaly, both designers were able to reassess their knowledge to overcome their fixation effects. Facing the anomaly P. Horvath's team were able to identify Clustered Regularly Interspaced Short Palindromic Repeats (CRISPR) when genotyping cell strains, a concept that he heard about in a scientific conference a few years ago. Having access to 10,000 acid lactic bacteria strains used in the company and Danisco expertise in that domain (Condition 4), they were able to demonstrate a correlation between presence of CRISPR in the genotypes of cell strains and resistance to phage (ie. it broadly act as a 'vaccine' but at a micro-organism level). They were the first research team to demonstrate this correlation by using empirical analyses. Furthermore, due to their commitment to provide both scientific and industrial response to this issue (Condition 5), the research team developed an industrial process to add phage DNA to acid-lactic bacteria in order to favour their resistance to

${ }^{2}$ The scientific discovery is mainly attributed to J. Doudna and E. Charpentier for their article in Science (Jinek et al., 2012)

${ }^{3}$ Main references includes: Lander works on scholars that made CRISPR (2015) ; Report for the French Senate from Le Deaut and Procaccia (2017) and Le Monde special focus on CRISPR (2016) 
viruses. They patented their invention (final application in 2006 at the USPTO) and the associated scientific article was published in Science in 2007. This project led to a cross-defixation process for both invention and scientific model and all the five conditions of our framework were valid.

\section{IMPLICATION AND FURTHER RESEARCH}

Our main objective was to understand under which conditions new invention and scientific model designers were able to partner in order to produce better creative and original outputs. We drew on $\mathrm{C}-\mathrm{K}$ theory and focused on fixation effects in order to interpret in which situations designers are able to provide outputs whether on a fixed design path or in an original path. We showed how design theories modelled both patentable inventions and scientific models that offered us a coherent and unified framework to deal with those issues. Our contributions are the following. (1) We proposed a first set of elements that can be suffering from fixation effects in both invention and scientific models designers reasoning and briefly explained what the main contributing factors are. (2) As examples in the defixed design path can help designers to propose new inventive solutions we propose a series of defixed inputs that could be shared between invention and scientific designers to help them to overcome their own fixation effects. We also provided a couple of historical examples. (3) We then used the matching building model to define the effect of invention and scientific model designers' partnerships on fixations. We showed that if partners are engaged in one-way knowledge transfer, those partnerships can conduct to "fixation traps": inventions and scientific models are sequential and linked to the fixed design path. (4) We defined a set of restrictive conditions that could conduct to a "cross-defixation process": both actors would be then able to create conjoint new invention and scientific model in the defixed design path.

Our findings seem consistent with current debates regarding science organisation. Indeed, "crossdefixation" processes advocate for strengthening partnerships between science and industry. A particular issue is that the parties do not necessary need to be "defixed" before starting the partnership: by setting particular conditions regarding the partnership design, both initially fixed designers might be able to provide original and creative outputs. The success conditions also led to highlight the importance of designer educations to detect what would be those defixated inputs and how to share them in the most efficient way. Furthermore, there is a need to conduct further analysis regarding those conditions and how it match with firms strategies (in particular regarding intellectual property stakes and strategies regarding the exchange of those defixated inputs). Further analysis have also to be carried out regarding associated management practices. Nevertheless, we shed light on a particular situation that conduct to "fixation traps": in those, as it is mainly a one-way exchange of knowledge, the probability that designers shared defixing example is low, and it can even strengthen fixation effects. We acknowledge that knowledge transfer between science and industry is key for national innovation system. But first, partners have to be aware of what they have to attempt from those partnerships in terms of creative outputs and those have to be aligned with management practices. Second, it would be easier for an organisation to define fixation effect mitigation procedures outside those kind of partnership in order to produce creative outputs. We think that focusing on fixation effects on science and industry collaborations could help scholars and practitioners to foster specific collaborations or framework success conditions (eg. collaborative $\mathrm{PhD}$ as the "CIFRE" scheme in France). In particular, further qualitative and quantitative research are necessary to confirm the model's insights.

\section{REFERENCES}

Agogué, M. (2012), "Modéliser l'effet des biais cognitifs sur les dynamiques industrielles : innovation orpheline et architecte de l'inconnu." Ecole Nationale Supérieure des Mines de Paris.

Agogué, M. et al. (2014), "The impact of type of examples on originality: Explaining fixation and stimulation effects", Journal of Creative Behavior, Vol. 48 No. 1, pp. 1-12. http://doi.org/10.1002/jocb.37.

Agogué, M. and Le Masson, P. (2014), "Rethinking ideation: a cognitive approach of innovation lock-ins", in The International Society for Professional Innovation Management, pp. 1-11. https://doi.org/10.5465/ambpp.2015.15303abstract.

Bush, V. (1945), Science, the endless frontier; a report to the President on a program for postwar scientific research. http://doi.org/B00B3K4WAA.

Camarda, A. et al. (2017), "The role of Expertise in Design Fixation : Managerial Implications for Creative Leadership", in The 24th Innovation and Product Development Management Conference, p. 11. https://doi.org/10.1002/jocb.37. 
des Comptes, C. (2018), Rapport particulier sur la valorisation de la recherche civile du CEA.

Le Deaut, J.-Y. and Procaccia, C. (2017), Les enjeux économiques, environnementaux, sanitaires et éthiques des biotechnologies à la lumière des nouvelles pistes de recherche. Paris, France. Available at: https://www.senat.fr/notice-rapport/2016/r16-507-1-notice.html.

Felk, Y. et al. (2011), "Designing Patent Portfolio for disruptive innovation - a new methodology based on C-K Theory”, International Conference on Engineering Design, ICED, Vol. 11 No. August, pp. 1-12.

Gibbons, M. et al. (1994), The New Production of Knowledge. SAGE Publications Ltd.

Gillier, T., Kazakçı, A. and Piat, G. (2012), "The Generation of Common Purpose in Innovation Partnerships : a Design Perspective”, European Journal of Innovation Management, Vol. 15 No. 3, pp. 372-392.

Goldstein, A. P. and Narayanamurti, V. (2018), "Simultaneous pursuit of discovery and invention in the US Department of Energy”, Research Policy. Elsevier, Vol. 47 No. 8, pp. 1505-1512. https://doi.org/10.1016/j.respol.2018.05.005.

Hatchuel, A. et al. (2013), "Beyond Models and Decisions : Situating Design Through Generative Functions", ICED13: 19th International Conference on Engineering Design, No. August, pp. 1-10. https://doi.org/<hal$01485144>$.

Hatchuel, A., Le Masson, P. and Weil, B. (2011), “Teaching innovative design reasoning: How concept-knowledge theory can help overcome fixation effects", AI EDAM, Vol. 25 No. 1, pp. 77-92. https://doi.org/10.1017/S089006041000048X.

Hatchuel, A. and Weil, B. (2003), “A new approach of innovative design: an introduction to C-K theory”, in International Conference on Engineering Design ICED 03, pp. 1-15. https://doi.org/citeulike-articleid:4891368.

Hatchuel, A. and Weil, B. (2009), “CK Design Theory: An Advanced Formulation”, Research in Engineering Design, Vol. 19 No. 4, pp. 181-192. https://doi.org/10.1007/s00163-008-0043-4.

Kaplan, S. and Tripsas, M. (2008), "Thinking about technology: Applying a cognitive lens to technical change", Research Policy, Vol. 37 No. 5, pp. 790-805. https://doi.org/10.1016/j.respol.2008.02.002.

Klasing Chen, M. et al. (2017), "Designing the missing link between science and industry: Organizing partnership based on dual generativity”, 21st International Conference on Engineering Design, ICED 2017, Vol. 4 No. DS87-4, pp. 307-316. Available at: https://www.scopus.com/inward/record.uri?eid=2-s2.0-85029744337 \&partnerID $=40 \& \mathrm{md} 5=$ c320dedd3652905ce1908e8ee60a78e5.

Kokshagina, O. et al. (2014), "Innovative field exploration and associated patent portfolio design models", in Research in Interactive Design, pp. 402-408. https://doi.org/10.1007/978-3-319-26121-8.

Krawczyk-Stuss, M. et al. (2015), "Evaluation of Shear Bond Strength of the Composite to Biodentine with Different Adhesive Systems", Dental and Medical Problems, Vol. 52 No. 4, pp. 434-439. https://doi.org/10.17219/dmp/59498.

Lander, E. S. (2015), "Perspective The Heroes of CRISPR”, Cell. Elsevier Inc., Vol. 164 No. 1-2, pp. 18-28. https://doi.org/10.1016/j.cell.2015.12.041.

Lenfle, S. (2011), "The strategy of parallel approaches in projects with unforeseeable uncertainty: The Manhattan case in retrospect”, International Journal of Project Management. Elsevier Ltd and IPMA, Vol. 29 No. 4, pp. 359-373. https://doi.org/10.1016/j.ijproman.2011.02.001.

Le Masson, P., Weil, B. and Hatchuel, A. (2014), Theorie, méthodes et organisations de la conception. Collection. Edited by P. des Mines.

Narayanamurti, V., Odumosu, T. and Vinsel, L. (2017), "RIP : The Basic / Applied Research Dichotomy", Issues in Science, Vol. 29 No. 2, pp. 31-36.

Sincholle, V. (2009), De la gestion des brevets d'inventions au pilotage de l'innovation: le cas d'un centre de recherche de haute technologie. Ecole Polytechnique.

Slaughter, S. (1993), "Beyond Basic Science: Research University Presidents' Narratives of Science Policy”, Science, Technology, \& Human Values, Vol. 18 No. 3, pp. 278-302. https://doi.org/10.1177/016224399301800302.

Stokes, D. (1997), Pasteur's Quadrant. Basic science and technological innovation. Brookings. Available at: https://courses.cs.washington.edu/courses/cse510/16wi/readings/stokes_pasteurs_quadrant.pdf.

Sydow, J., Freie, U. B., Schreyögg, G., Freie, U. B., Koch, J. and European, U. V. (2009), “Organizational Path Dependence: opening the black box", Academy of Management Review, Vol. 34 No. 4, pp. 689-709. Available at: https://doi.org/10.5465/amr.34.4.zok689.

Thrane, S., Blaabjerg, S. and Møller, R. H. (2010), "Innovative path dependence: Making sense of product and service innovation in path dependent innovation processes", Research Policy. Elsevier B.V., Vol. 39 No. 7, pp. 932-944. https://doi.org/10.1016/j.respol.2010.04.003.

\section{ACKNOWLEDGMENTS}

We acknowledge the very useful insights gave by Frédéric Caillaud, Deputy Director at Institut National de la Propriété Industrielle and in charge of innovation and Valérie Archambault, Deputy Director of Research at Mines Paristech PSL. 